\title{
The first record of a pre-Columbian domestic dog (Canis lupus familiaris) in Brazil
}

Suggested Running Head: First record of pre-Columbian domestic dog in Brazil

Rafael Guedes Milheira ${ }^{\mathrm{a}}$, Daniel Marcelo Loponte ${ }^{\mathrm{b}}$, César García Esponda ${ }^{\mathrm{c}}$, Alejandro Acosta $^{\mathrm{b}}$, Priscilla Ulguim ${ }^{\mathrm{d} *}$

${ }^{a}$ Department of Anthropology and Archaeology, Universidade Federal de Pelotas. Laboratory of Anthropology and Archaeology (LEPAARQ/UFPEL). Pelotas. Brazil. milheirarafael@gmail.com

${ }^{\mathrm{b}}$ Instituto Nacional de Antropología y Pensamiento Latinoamericano (INAPL). Consejo Nacional de Investigaciones científicas y Técnicas (CONICET). Calle 3 de Febrero 1378 (CJ1426N). Buenos Aires. Argentina. dloponte@inapl.gov.ar; acosta@retina.ar

${ }^{c}$ Universidad Nacional de La Plata. Facultad de Ciencias Naturales y Museo. Paseo del Bosque s/n. 1900. La Plata. Argentina. cesponda@fcnym.unlp.edu.ar

d School of Science \& Engineering, Teesside University, Middlesbrough, TS1 3BA, UK. ORCID 0000-0002-5563-5682. p.ulguim@tees.ac.uk *

*Corresponding Author (Tel: +44 7449949798)

Keywords: Canis lupus familiaris; Brazil; Zooarchaeology; Isotope Analysis; Earthen mounds

This article has been accepted for publication and undergone full peer review but has not been through the copyediting, typesetting, pagination and proofreading process which may lead to differences between this version and the Version of Record. Please cite this article as doi: $10.1002 /$ oa.2546 


\begin{abstract}
Archaeological excavations of the PSG-07 earthen mound at Pontal da Barra in Rio Grande do Sul, southern Brazil have revealed the earliest known evidence for the presence of domestic dog (Canis lupus familiaris) in Brazil. This is the first reported pre-Columbian example in the country. Analysis of morphology, morphometry, and dental enamel laminae identified a left maxillary molar 1, left maxillary molar 2 and attached fragments of the maxilla of Canis lupus familiaris. A direct radiocarbon date on a fragment of the maxilla provided an age range between 1701 and $1526 \mathrm{cal} \mathrm{BP}(2 \sigma)$. This is within the range of other dates for the site, which indicate intermittent occupation between 2024 and 1027 cal BP $(2 \sigma)$. Data from carbon isotope analysis indicates a potential marine diet. However, nitrogen isotope analysis values are lower than expected for a marine diet. The sparse records of preColumbian Canis lupus familiaris in the region emphasise the importance of the present work.
\end{abstract}

\title{
1. Introduction
}

Within South America, securely identified remains of pre-Columbian Canis lupus familiaris (C. l. familiaris), the domestic dog, are mostly limited to the Andes and neighbouring regions. The paucity of remains elsewhere contrasts with the broad expansion of dogs from ca. 10000 BP throughout North and Central America, (Morey, 2006). In South America, their introduction appears to take place later, between ca. 7500 and 4500 BP (Cabrera, 1934; Gallardo, 1964-65; Mendoza and Valadez, 2006; Pozzi-Escot et al., 2012; Prates et al., 2010a; Schwartz, 1997; Wing, 1989; Zetti, 1973). Beyond the Andes, finds pertain to preColumbian C. l. familiaris in Argentina (Acosta and Loponte, 2010; 2011), yet there are just six undisputed published cases. Two are from north Patagonia (Prates et al., 2010a) and four from the lower Paraná wetlands (Acosta and Loponte, 2010; Acosta et al., 2011; 2015). In Uruguay, there is further evidence from perhaps four earthen mound sites, although several of the zooarchaeological analyses remain in unpublished literature (Bracco et al., 2000; González, 1999; López Mazz and Castiñeira, 2001; Rudolph, 2014).

This report presents the first archaeological record of pre-Columbian C. l. familiaris from Brazil. The evidence comprises two complete maxillary molars - M1 and M2, with a small fragment of a left maxilla attached (ID: 115-04). These are from a complex of 18 earthen mounds in Pontal da Barra, southern Brazil (Figure 1) (Milheira, 2014). The mounds are archaeological deposits known as cerritos de indios or aterros. Such sites appear across the Pampa biome in the lowlands of the La Plata Basin, its southern coast including areas of modern Brazil, Uruguay and Argentina (López Mazz, 2001). Research indicates that these developed through successive occupation by complex hunter-gatherers in the wetland environments of the region over a long period, from as early as ca. 5000 BP until 200 BP (Bracco et al., 2008; Gianotti, 2015; Iriarte, 2006; Schmitz, 1976). PSG-07 is a sub-circular mound with a greatest width of $36 \mathrm{~m}$, aligned with three other earthen mounds on a NorthSouth axis. The molars were recovered from Level 2 of the excavation. Lithic fragments, 
potsherds, faunal and fragmented human remains were recorded across other levels (Milheira, 2014). Radiocarbon dates from the complex suggest intermittent occupation between 2024 and 1027 cal BP $(2 \sigma)$ (Table 1). Evidence indicates hunter-gatherer use of lacustrine resources from Lagoa dos Patos, a post-glacial coastal lagoon.

Figure 1. A: Location of the Pontal da Barra complex in South America, and; B: in the coastal region of southern Brazil with other records of pre-Columbian dogs as per Table 3 shown in yellow. C: Location in relation to regional mound sites. D: PSG-07 within the complex at UTM 22J 383093/6483337.

Table 1. Radiocarbon dates from PSG-07 at the Pontal da Barra earthen mound complex after Milheira et al., 2016b. Type $1=$ date on C. l. familiaris taxon; $2=$ date from context. *Calibrated with OxCal 4.2 using SHCAL13 for terrestrial flora and fauna, Marine13 curve used for marine fauna (otoliths) (Bronk-Ramsey, 2009; Hogg et al., 2013; Reimer et al., 2013).

\section{Methods}

The excavation of a $3 \times 1 \mathrm{~m}$ unit at PSG-07 during 2013 revealed the $C$. l. familiaris remains. Members of the research team compared both molars with $C$. l. familiaris specimens at the Museo de La Plata, Argentina, including a pre-Columbian individual (INAPL/CL1-UE-3) from the Paraná Delta, morphologically and genetically identified as C. l. familiaris (Acosta et al., 2011). Furthermore, the team made comparisons with American foxes including Chrysocyon brachyurus, Lycalopex gymnocercus, Cerdocyon thous and Dusicyon avus, and to bibliographic data on Lycalopex vetulus (Dalponte, 2009). Molar enamel laminae patterning was examined by binocular microscope and compared with reference material, as the arrangement of dental enamel laminae (Hunter-Schreger bands) may distinguish dogs from foxes (Stefen, 1999). Standard measurements (Hillson, 1996) were completed three times by the same individual with digital callipers, and the mean value provided to the nearest $0.01 \mathrm{~mm}$. Isotope values and radiocarbon ages derive from collagen samples of the maxilla fragment (Milheira et al., 2016b).

\section{Results}

The left first and second upper molars are identified as domestic dog (C. l. familiaris) along with fragments of the respective maxilla. Measurements are comparable to other mediumsized specimens of $C$. $l$. familiaris specimens of the region (Table 2). This means that individuals of similar sizes were circulating in the area during the late Holocene (González, 1999; Loponte and Acosta, 2016). 
Table 2. Measurements of the PSG-07 C. l. familiaris dentition compared to data on the left maxillary M1 from Chenque 1 and from Cerro Lutz. The M1 from PSG-07 is similar in size to that at Cerro Lutz; the Chenque 1 M1 is smaller than the other two. Estimates of height at the shoulder were calculated from the long bones of the individuals found at Cerro Lutz (Tibia and Femur) and Chenque 1 (Humerus, Radius, Ulna and Tibia). No M2 was found at the other two sites.

Morphological features distinguish these teeth from those of South American wild canids. In C. l. familiaris tooth cusps are blunter and more robust than in wild species; the paracones of both molars are conspicuously larger than their respective metacones; the lingual cinguli and hypocones of both molars are reduced compared with those of wild foxes (Prates et al., 2010a; Tedford et al., 1995). These features are observable on the specimens from PSG-07. Moreover, other features of the molars of South American foxes differ. The molars of $C$. brachyurus are larger and proportionally narrower in their mesiodistal length; those of $L$. gymnocercus and $C$. thous are more extended transversely; those of L. vetulus are subquadrate, with little buccolingual extension (Figure 2).

Figure 2. The upper image is of the left maxillary molar 1; the lower is of the left maxillary molar 2 of C. l. familiaris recovered from PSG-07 (ID: 115-04). Labial view to the left, occlusal view to the right.

Dental enamel laminae patterning in both molars differ from South American foxes. $C$. $l$. familiaris molars transition from an undulating arrangement of the Hunter-Schreger bands to a zigzag arrangement. The bands of compared wild South American species undulate, an observation which agrees with previous studies (Prates et al., 2010a; Stefen, 1999). The zigzag arrangement is associated with carnivorous canid species that also consume bone to some extent, such as C. l. familiaris (Stefen, 1999). The simpler undulating arrangement observed in all South American foxes compared here is likely linked to their omnivorous diet.

A direct date obtained from bone collagen of the maxilla yielded a conventional radiocarbon age of 1701-1526 cal BP $(2 \sigma)$ (Beta-415598) consistent with the date range for human occupation of the site (Milheira et al., 2016a; 2016b) (Table 1). Results of isotope analysis (C/N: 3.1) of the maxilla were Carbon: $\delta^{13} \mathrm{C}-11.4 \%$, Nitrogen: $\delta^{15} \mathrm{~N}-10.6 \%$.

\section{Discussion and Conclusion}

The spread of $C$. $l$. familiaris throughout South America occurs later than in North and Central America, and appears limited in extent beyond the Andean region until the period of European contact. The handful of sites in the south of the continent with clearly identified pre-Columbian C. l. familiaris remains are close to PSG-07 in distance and date. Confirmed finds come from the Pampas, at Cerro Lutz in the lower Paraná basin in Argentina, about 
$700 \mathrm{~km}$ away (Acosta et al., 2011), the more distant Chenque I, as well as northern Patagonia at Angostura I (Prates et al., 2010a). Evidence from Uruguay reveals perhaps four sites approximately $450 \mathrm{~km}$ south, like PSG-07 these are earthen mounds (Bracco et al., 2000; González, 1999; López Mazz and Castiñeira, 2001; Loponte and Acosta, 2016; Rudolph, 2014). The date of 1701-1526 cal BP $(2 \sigma)$ for the Pontal da Barra remains is in the upper range associated with $C$. $l$. familiaris at regional sites, and within the range of those in Eastern Uruguay. Remains found further west in the Lower Uruguay River, Paraná River and North Patagonia are later in date. This may relate to the expansion of pre-Columbian $C . l$. familiaris in this region (Table 3).

Table 3. Records of pre-Columbian dogs in south-eastern South America: Type $1=$ date on taxon; 2 = date from context (after Acosta et al. 2011; 2015), (OxCal 4.2, SHCAL13). See Figure 1 for their locations in relation to the study site.

While Andean sites with pre-Columbian C. l. familiaris pertain to sedentary agricultural societies (Gallardo, 1964-1965), sites across Patagonia and the Pampas of Brazil, Argentina and Uruguay relate to hunter-gatherer occupations. Many authors suggest the value of the dog in the cooperative hunting of larger-sized prey (Lupo, 2011), but although dogs supported hunting in some neotropical societies, in many they served only as pets or as a food source (Koster, 2009). Thus, it is important to understand the niche that dogs occupied in each society, both economically and symbolically. In this case and regional examples, their deposition in potential funerary contexts may point to a possible interpretation (Morey, 2006). At Chenque I a complete $C$. l. familiaris skeleton was apparently buried deliberately with a sub-adult human male (Prates et al., 2010a). At Cerro Lutz Acosta et al. (2011) argue that the complete and articulated dog remains result from deliberate burial by humans, and there is evidence for later human burials on site. There is a strong association between $C$. $l$. familiaris remains and human burials in the earthen mounds noted in Uruguay at Potrerillo de Santa Teresa (López Mazz and Castiñeira, 2001), Puntas de San Luis (Bracco et al., 2000) and CH2D01, San Miguel, where one of two articulated canid skeletons was recovered close to human remains (González, 1999), although Rudolph (2014) was not able to confirm the identification of these remains as C. l. familiaris. At PSG-07 the C. l. familiaris remains appeared approximately 40-60 $\mathrm{cm}$ above three dispersed fragments of human cranial bone and an unerupted crown of human left maxillary M1. Current research aims to contextualise these finds.

Analysis of carbon and nitrogen isotopes provides dietary information. The carbon value, $\delta^{13} \mathrm{C}-11.4 \%$, is typical of a marine diet, and close to others obtained from samples at archaeological sites on the seashore of the adjacent state of Santa Catarina (Colonese et al., 2014; Bastos et al., 2015; Loponte et al., 2016). The value obtained in nitrogen, $\delta^{15} \mathrm{~N}$ $10.6 \%$, is lower than expected for diets based on marine resources. This value cannot be discarded as an outlier as the nitrogen value might be influenced by the intake of plants 
within a $\mathrm{C}_{4}$ photosynthetic pattern such as maize, whose cultivation is being evaluated on the basis of other lines of evidence (Mühlen, 2014; Milheira, 2014). Future isotopic analysis of human remains recovered at this site will permit improved interpretation of these results, given the similarity between human and domestic canid diets (Bartelink, 2009; Byrd et al., 2013; Rick et al., 2011).

In conclusion, the presence of $C$. $l$. familiaris at PSG-07 provides evidence for the first known pre-Columbian domestic dog in Brazil. This find expands the data set of identified remains at earthen mound sites on the Atlantic coast of South America, contributing to the discussion on the distribution and expansion of domestic canids in the region (Koster, 2009; Pozzi-Escot et al., 2012; Stahl, 2013). The discovery aids our interpretations of past excavations and raises both questions and expectations in the archaeology of south-eastern South America.

\section{Acknowledgements}

The authors acknowledge support from CNPq (470178/2013-2). There are no known conflicts of interest associated with this work.

\section{References}

Acosta, A, Loponte, D. 2010. Registro de perros prehispánicos (Canis familiaris) en el sector centro-oriental de la Región pampeana. In Arqueología Argentina en el Bicentenario de la Revolución de Mayo V, Bárcena, JR, Chiavaza, H. (eds.). Mendoza; 1823-1828.

Acosta, A, Loponte, D. 2011. Reseña histórica sobre los perros prehispánicos de la República Argentina (Parte 1). AMMVEPE, Revista de la Asociación Mexicana de Médicos Veterinarios Especialistas en Pequeñas Especies 22(4): 100-105.

Acosta A, Loponte, D, García Esponda, C. 2011. Primer registro de perro doméstico prehispánico (Canis familiaris) entre los grupos cazadores recolectores del humedal de Paraná inferior (Argentina). Antípoda Revista de Antropología y Arqueología 13: 175-199.

Acosta, A, Buc, N, Ramírez, M, Prevosti, F, Loponte, D. 2015. Producción y uso de objetos ornamentales elaborados sobre dientes de carnívoros en contextos arqueológicos del humedal del Paraná inferior. Revista del Museo de Antropología 8(2): 33-46.

Bartelink, EJ. 2009. Late Holocene dietary change in the San Francisco Bay area: stable isotope evidence for an expansion in diet breadth. California Archaeology 1(2): 227 252.

Bastos, MQR, Santos, RV, Tykot, RH, Mendonça de Souza, SMF, Rodrigues-Carvalho, C, Lessa, A. 2015. Isotopic evidences regarding migration at the Archaeological Site of 
Praia da Tapera: New data to an old matter. Journal of Archaeological Science: Reports 4: 588-595.

Bracco, R, Montaña, J, Nadal, O, Gancio, F. 2000. Técnicas de Construcción y Estructuras Monticulares. Termiteros y Cerritos: Desde lo Analógico a lo Estructural. In Arqueología de las Tierras Bajas, Duran Coirolo, A, Bracco, R. (eds.). Ministerio de Educación y Cultura. Comisión Nacional de Arqueología. Montevideo; 285-300.

Bracco, R, Puerto, L. del, Inda, H, 2008. Prehistoria y Arqueología de la Cuenca de Laguna Merín. In Entre la Tierra y el Agua. Arqueología de Humedales de Sudamérica, Loponte, D, Acosta, A. (eds.). AINA: Buenos Aires; 1-60.

Bronk-Ramsey, C. 2009. Bayesian analysis of radiocarbon dates. Radiocarbon 51(3): 10231045.

Byrd, BF, Cornellas, A, Eerkens, JW, Rosenthal, JS, Carpenter TR, Leventhal, A, Leonard, JA. 2013. The role of canids in ritual and domestic contexts: new ancient DNA insights from complex hunter-gatherer sites in prehistoric Central California. Journal of Archaeological Science 40: 2176-2189.

Cabrera, A. 1934. Los perros domésticos de los indígenas del territorio argentino. $25^{\circ}$ Congreso Internacional Americanistas 1: 83-93.

Colonese, A, Collins M, Lucquin, A, Eustace M, Hancock, Y, Almeida, R, Ponzoni, R, Mora, A, Smith, C, De Blasis, P, Figuti, L, Wesolowski, V, Plens. R, Eggers, S, Farias, D, Gledhill, A, Craig, O. 2014. Long-Term Resilience of Late Holocene Coastal Subsistence System in Southeastern South America. PLoS ONE 9(4)e93854: 1-13.

Dalponte, JC. 2009. Lycalopex vetulus. Mammalian Species 847: 1-7.

Gallardo, G. 1964-1965. Perros americanos precolombinos. Cuadernos del Instituto Nacional de Antropología y Pensamiento Latinoamericano 5: 31-69.

Gianotti, C. 2015. Paisajes Sociales, Monumentalidad y Territorio en las tierras bajas de Uruguay. Santiago de Compostela. Thesis.

González, R. 1999. Canis familiaris y constructores de cerritos: una perspectiva funeraria. Taller II de Arqueología, FHCE - Montevideo. Unpublished.

Hillson, S. 1996: Teeth. Cambridge University Press: Cambridge.

Hogg, AG, Hua, Q, Blackwell, PG, Niu, M, Buck, CE, Guilderson, TP, Heaton TJ, Palmer, JG, Reimer, PJ, Reimer RW, Turney, CSM, Zimmerman, SRH. 2013. SHCal13 Southern Hemisphere calibration, 0-50,000 years cal BP. Radiocarbon 55(4): 18891903. 
Iriarte, J. 2006. Transformation, Mounded Villages and Adopted Cultigens: The Rise of Early Formative Communities in South-Eastern Uruguay. World Archaeology 38(4): 644663.

Koster, J. 2009. Hunting dogs in the lowland Neotropics. Journal of Anthropological Research 65: 575-610.

López Mazz, JM. 2001. Las estructuras tumulares de la Cuenca de la Laguna Merín. Latin American Antiquity 12(3): 231-255.

López Mazz, JM, Castiñeira, C. 2001. Estructura de sitio y patron de asentamiento en la Laguna Negra (depto. de Rocha). Arqueología uruguaya hacia el fin del milenio: IX Congreso Nacional de Arqueología. Uruguay; 147-174.

Loponte, D, Acosta. A. 2016. Nuevos registros de Canis familiaris (Carnivora, Canidae) en la cuenca del Paraná, Argentina. Mastozoología Neotropical. In press.

Loponte, D, Carbonera, C, Corriale, MJ, Acosta, A. 2016. Horticulturists and oxygen ecozones in the tropical and subtropical forests of Southeast South America. Environmental Archaeology: The Journal of Human Palaeoecology. DOI: 10.1080/14614103.2016.1211382. In Press.

Lupo, K. 2011. A dog is for hunting. In Ethnozooarchaeology: The Present and Past of Human-Animal Relationships, Albarella, U, Trentacoste, A. (eds.). Oxbow Press: Oxford; 4-12.

Mendoza España, V, Valadez, R. 2006. El perro prehispánico andino: función y tipos a partir del análisis arqueozoológico. Anales de la XIX Reunión Anual de Etnología, Museo Nacional de Etnografía y Folklore: La Paz, Bolivia; 31-38.

Milheira, RG. 2014. Arqueologia e História indígena do Pampa: estudo das populações précoloniais na bacia hidrográfica da Laguna dos Patos e Lagoa Mirim. Unpublished Report.

Milheira, RG, Garcia, AM, Ulguim, PF, Silveira, CS, Ricardo Ribeiro, BL. 2016a. Arqueologia dos cerritos na Laguna dos Patos, sul do Brasil: uma síntese da ocupação regional. Cadernos do Ceom. Estudos regionais de arqueologia 45(2). In press.

Milheira, RG, Macario, K, Chanca, I, Alves, EQ. 2016b. Archaeological earthen mound complex in Patos Lagoon, Southern Brazil: chronological model and freshwater influence. Journal of Environmental Radioactivity. In Press.

Morey, DF. 2006. Burying key evidence: the social bond between dogs and people. Journal of Archaeological Science 33: 158-175.

Mühlen, CV. 2014. Humanos, plantas e paisagem: a Arqueopalinologia como ferramenta para análise dos processos formativos do Cerrito PSG-02 Valverde, Pelotas, RS. UFPel: Pelotas 
Pozzi-Escot, D, Cornejo Rivera, I, Costaneira, EA, Bernuy Quiroga, K, 2012. Estudio preliminar de los hallazgos de Canis familiaris en la Pirámide con Rampa $\mathrm{n}^{\circ}$, Santuario de Pachacamac, Perú. Revista del Museo de Antropología 5: 171-184.

Prates, L, Prevosti, FJ, Berón, M. 2010a. First records of prehispanic dogs in Southern South America (Pampa-Patagonia, Argentina). Current Anthropology 51: 273-280.

Prates, L, Berón, M, Prevosti, FJ. 2010b. Los perros prehispánicos del Cono Sur: Tendencias y nuevos registros. In Mamül Mapu: pasado y presente desde la arqueología pampeana, Berón, M, Luna, L, Bonomo, M, Montalvo, C, Aranda C, Carrera Aizpitarte, M. (eds.). Editorial Libros del Espinillo: Ayacucho; 215-228.

Reimer, P, Bard, E, Bayliss, A, Beck, J, Blackwell, P, Bronk Ramsey, C, Buck, C, Cheng, H, Edwards, R, Friedrich, M, et al. 2013. IntCal13 and Marine13 Radiocarbon Age Calibration Curves 0-50,000 Years cal BP. Radiocarbon 55(4): 1869-1887.

Rick, T, Culleton, C, Brendan, J, Smith, C, Johnson, B, Kennett J, Douglas, J. 2011. Stable isotope analysis of dog, fox, and human diets at a Late Holocene Chumash village (CA-SRI-2) on Santa Rosa Island, California. Journal of Archaeological Science 38: 1385-1393.

Rudolph, FM. 2014. La gestión de los recursos animales en la prehistoria del este de Uruguay (4000 años AP - siglo XVI). Universitat Autònoma de Barcelona. Thesis.

Schwartz, M. 1997. A history of dogs in the early Americas. Yale University Press: New Haven.

Schmitz, PI. 1976, Sítios de Pesca lacustre em Rio Grande, RS, Brasil. UNISINOS. Thesis.

Stahl, P. 2013. Early dogs and endemic South American canids of the Spanish main. Journal of Anthropological Research 69: 515-533.

Stefen, C. 1999. Enamel microstructure of recent and fossil Canidae (Carnivora, Mammalia). Journal of Vertebrate Paleontology 19: 576-587.

Tedford RH, Taylor, BE, Wang, X. 1995. Phylogeny of the Caninae (Carnivora: Canidae): the living taxa. American Museum Novitates 3146: 1-37.

Wing, E. 1989. Human use of canids in the central Andes. In Advances in Neotropical Mammalogy, Redford, K, Eisenberg, J. (eds.). Gainesville: Sandhill Crane Press; 265278.

Zetti, J. 1973. Paleoetnozoología del Tastil. In Tastil, una ciudad preincaica argentina, Cigliano, EM. (ed.). Buenos Aires; 565-578. 


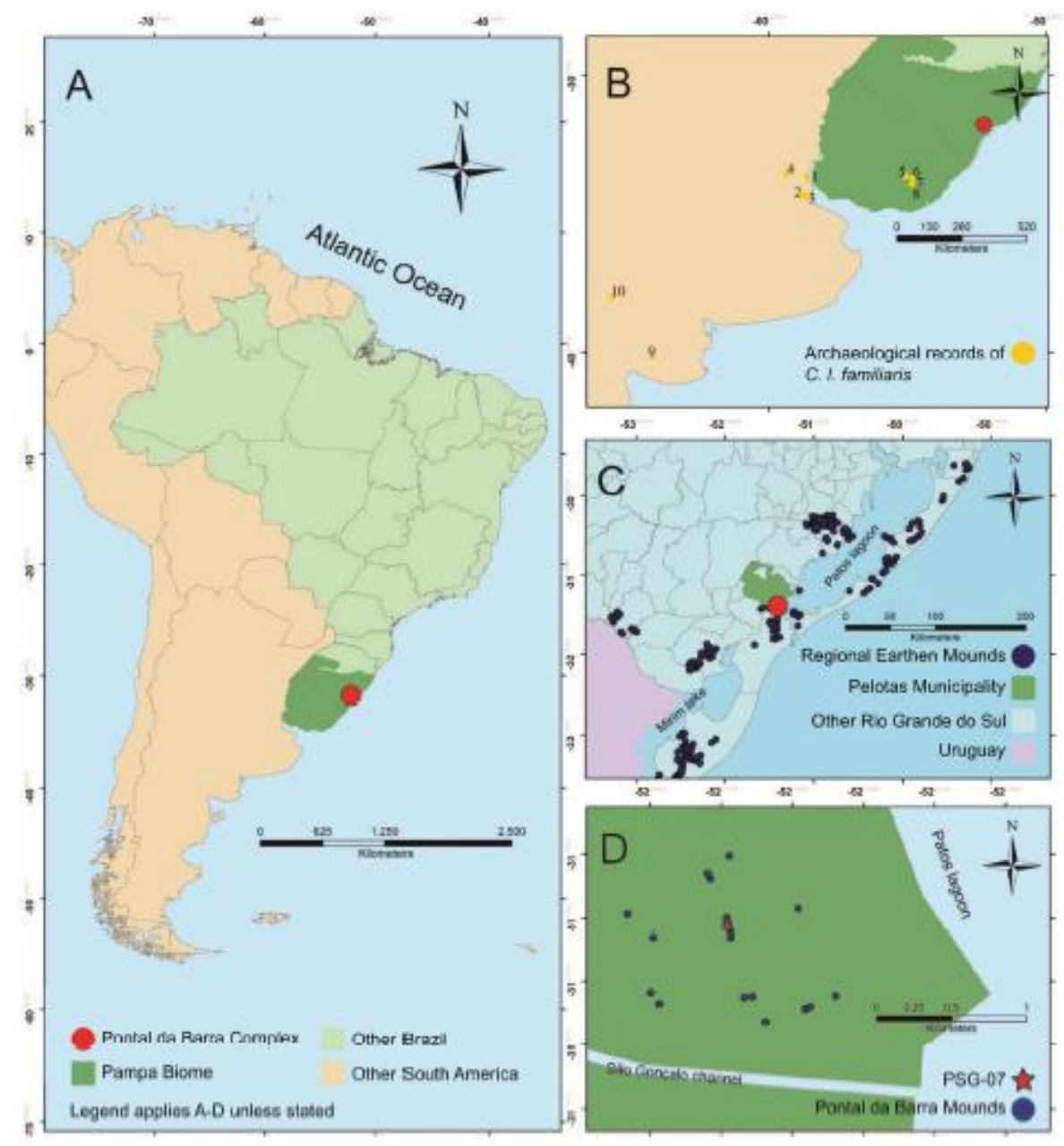

Figure 1. A: Location of the Pontal da Barra complex in South America, and; B: in the coastal region of southern Brazil with other records of pre-Columbian dogs as per Table 3 shown in yellow. C: Location in relation to regional mound sites. D: PSG-07 within the complex at UTM 22J 383093/6483337. 


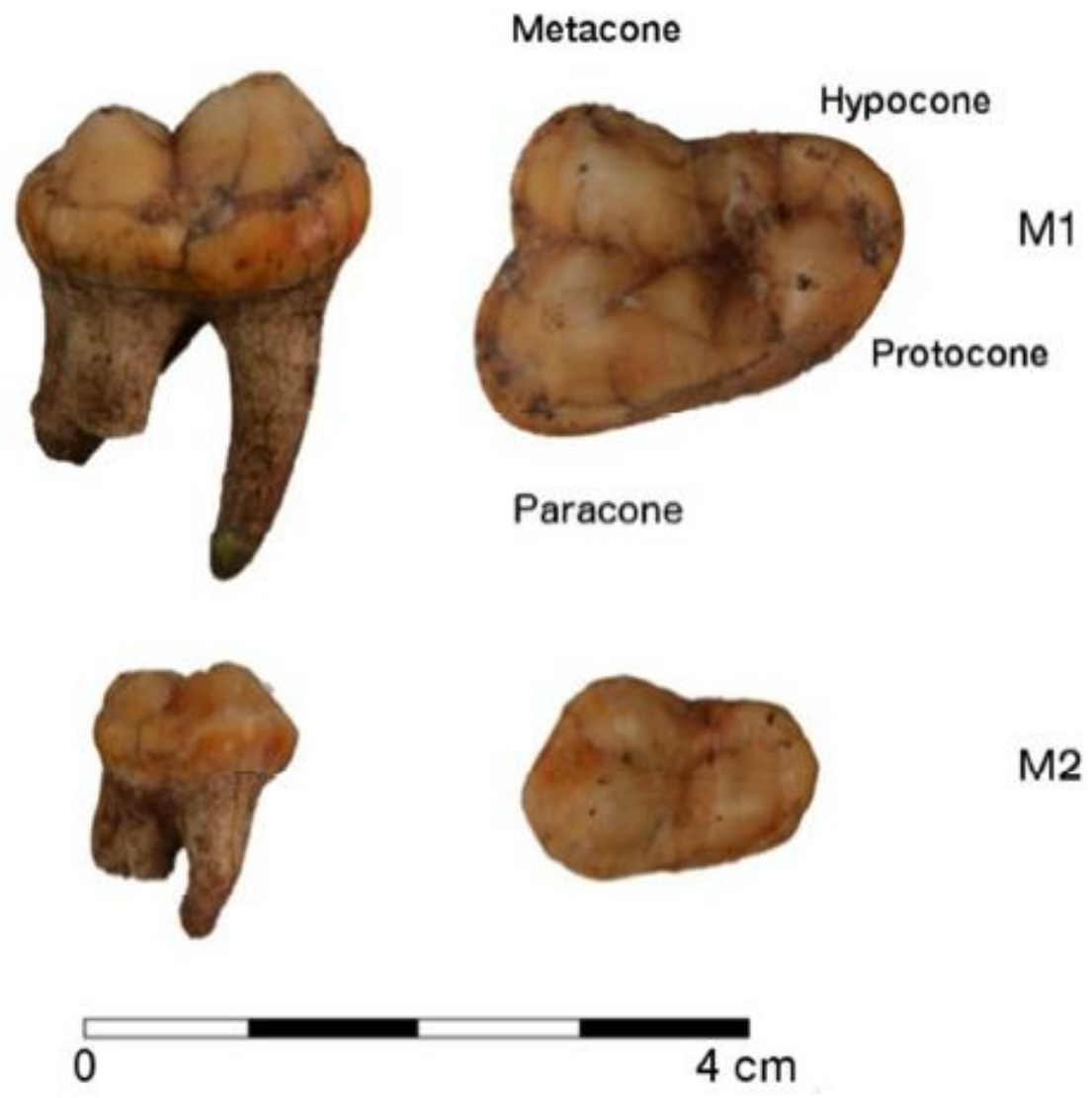

Figure 2. The upper image is of the left maxillary molar 1 ; the lower is of the left maxillary molar 2 of $\mathrm{C}$. I. familiaris recovered from PSG-07 (ID: 115-04). Labial view to the left, occlusal view to the right. 


\begin{tabular}{|c|c|c|c|c|c|}
\hline PSG-07 Sample & Cal BP $(2 \sigma)^{*}$ & ${ }^{14} \mathrm{C}$ yr BP & Type & $\begin{array}{r}\text { Excavated at } \\
\text { Depth }(\mathrm{cm})\end{array}$ & Lab Code \\
\hline C. l. familiaris maxilla (bone) & $1701-1526$ & $1720 \pm 30$ & 1 & 2.5 & Beta-415598 \\
\hline Otolith (bone) & $1686-1368$ & $1696 \pm 28$ & 2 & 5.0 & LACUFF-140396 \\
\hline Otolith (bone) & 2024-1289 & $2340 \pm 150$ & 2 & 22.5 & LACUFF-13052 \\
\hline Otolith (bone) & $1654-1027$ & $1214 \pm 22$ & 2 & 42.5 & LACUFF-140393 \\
\hline Charcoal & $1675-1323$ & $1660 \pm 190$ & 2 & 57.5 & LACUFF-140394 \\
\hline Otolith (bone) & $1705-1408$ & $1756 \pm 28$ & 2 & 57.5 & LACUFF-140395 \\
\hline Otolith (bone) & $1608-1356$ & $1670 \pm 30$ & 2 & 67.5 & Beta-389013 \\
\hline Charcoal & $1545-1407$ & $1630 \pm 30$ & 2 & 82.5 & Beta-389014 \\
\hline
\end{tabular}

Table 1. Radiocarbon dates from PSG-07 at the Pontal da Barra earthen mound complex after Milheira et al., 2016b. Type 1 = date on C. l. familiaris taxon; 2 = date from context. *Calibrated with OxCal 4.2 using SHCAL13 for terrestrial flora and fauna, Marine13 curve used for marine fauna (otoliths) (Bronk-Ramsey, 2009; Hogg et al., 2013; Reimer et al., 2013). 


\begin{tabular}{|c|c|c|c|c|c|}
\hline Specimen & Element & $\begin{array}{r}\text { Mesiodistal } \\
\text { length }(\mathrm{mm})\end{array}$ & $\begin{array}{r}\text { Labiolingual } \\
\text { width }(\mathrm{mm})\end{array}$ & $\begin{array}{l}\text { Est. Height at } \\
\text { Shoulder }(\mathrm{cm})\end{array}$ & Reference \\
\hline $\begin{array}{l}\text { 115-04 } \\
\text { PSG-07, Brazil }\end{array}$ & $\begin{array}{l}\text { Maxillary } \\
\text { Left M1 }\end{array}$ & 12.49 & 14.54 & $\mathbf{n} / \mathbf{a}$ & This work \\
\hline $\begin{array}{l}\text { 115-04 } \\
\text { PSG-07, Brazil }\end{array}$ & $\begin{array}{l}\text { Maxillary } \\
\text { Left M2 }\end{array}$ & 6.84 & 9.91 & $\mathbf{n} / \mathbf{a}$ & This work \\
\hline $\begin{array}{l}\text { INAPL/CL1-UE-3 } \\
\text { Cerro Lutz, Argentina } \\
\text { (Table 3: ID 1) }\end{array}$ & $\begin{array}{l}\text { Maxillary } \\
\text { Left M1 }\end{array}$ & 12.2 & 16.00 & 47 & Acosta et al., 2011 \\
\hline $\begin{array}{l}\text { ME E 41-2 } \\
\text { Chenque 1, Argentina } \\
\text { (Table 3: ID 10) }\end{array}$ & $\begin{array}{l}\text { Maxillary } \\
\text { Left M1 }\end{array}$ & 9.39 & 11.53 & 47 & Prates et al., 2010b \\
\hline
\end{tabular}

Table 2. Measurements of the PSG-07 C. l. familiaris dentition compared to data on the left maxillary M1 from Chenque 1 and from Cerro Lutz. The M1 from PSG-07 is similar in size to that at Cerro Lutz; the Chenque 1 M1 is smaller than the other two. Estimates of height at the shoulder were calculated from the long bones of the individuals found at Cerro Lutz (Tibia and Femur) and Chenque 1 (Humerus, Radius, Ulna and Tibia). No M2 was found at the other two sites. 


\begin{tabular}{llccccc}
\hline ID & Sites & Cal BP (26) & ${ }^{14}$ C yr BP & Type & Lab Code & Location \\
\hline 1 & Cerro Lutz & $906-689$ & $916 \pm 42$ & 1 & AA-77312 & Lower Uruguay River \\
\hline 2 & La Bellaca sitio 2 & $721-518$ & $680 \pm 80$ & 2 & LP-1263 & Lower Paraná River \\
\hline 3 & Anahí & $1050-735$ & $1020 \pm 70$ & 2 & Beta-147108 & Lower Paraná River \\
\hline 4 & La Argentina & $928-758$ & $979 \pm 44$ & 2 & AA-103642 & Lower Paraná River \\
\hline 5 & CH2D01 (Elevación B) & $1160-788$ & $1090 \pm 70$ & 2 & URU 002 & Eastern Uruguay \\
\hline 6 & CH2D01 (Microrelieve) & $1568-1352$ & $1610 \pm 50$ & 2 & URU 030 & Eastern Uruguay \\
\hline 7 & Potrerillo Sta. Teresa (Cerrito A) & $2420-2150$ & $2320 \pm 50$ & 2 & URU 082 & Eastern Uruguay \\
\hline 8 & Puntas de San Luis (Elevación 1) & $3888-3399$ & $3430 \pm 100$ & 2 & URU 0099 & Eastern Uruguay \\
\hline 9 & Angostura 1 & $918-730$ & $938 \pm 45$ & 2 & AA-2551 & North Patagonia \\
\hline 10 & Chenque 1 & $905-730$ & $930 \pm 30$ & 1 & UGA 02006 & North Patagonia
\end{tabular}

Table 3. Records of pre-Columbian dogs in south-eastern South America: Type 1 = date on taxon; 2 = date from context (after Acosta et al. 2011; 2015), (OxCal 4.2, SHCAL13). See Figure 1 for their locations in relation to the study site. 